\title{
Relations between Depression, Alcohol and Gender in the Metropolitan Region of São Paulo, Brazil
}

\author{
Relações entre depressão, álcool e gênero \\ na região metropolitana de São Paulo, Brasil
}

\begin{abstract}
Juliana de Almeida Prado ${ }^{1}$
Florence Kerr-Corrêa ${ }^{2}$

Maria Cristina Pereira Lima ${ }^{2}$

Giovanni Gurgel Aciole da Silva ${ }^{3}$

Jair Lício Ferreira Santos ${ }^{4}$
\end{abstract}

${ }^{1}$ Coordenadoria de Saúde e Segurança do Trabalhador e Sustentabilidade Ambiental, Universidade Estadual Paulista (UNESP). R. Quirino de Andrade 215, Centro. 01049-010 São Paulo SP.

jjbrprado@gmail.com

${ }^{2}$ Departamento de Neurologia e Psiquiatria,

Faculdade de Medicina de Botucatu (UNESP)

${ }^{3}$ Departamento de Medicina Preventiva, Faculdade de Medicina, UNIFESP.

${ }^{4}$ Departamento de Medicina Social, Faculdade de

Medicina de Ribeirão Preto, Universidade de São Paulo.

\begin{abstract}
As part of the GENACIS project, this paper sought to assess the prevalence of depression in an urban sample in the city of São Paulo, Brazil, as well as the association between depression and alcohol abuse according to gender. To achieve this, an epidemiological survey was conducted using a stratified probability sample, including 2,083 adults. CIDI SF was used to identify depression. The Rao Scott test and multivariate logistic regression were used for statistical analysis. The response rate was $74.9 \%$. Females (58.3\%) under 40 years of age (52\%) were predominant. The prevalence of depression was $28.3 \%$ for women and $12.7 \%$ for men. Most men declared being drinkers (61.1\%) in the last year. Depression was associated with an alcohol drinking pattern, mostly binge drinking, in addition to the occurrence of problems derived from alcohol use. Most women declared being abstainers (69.5\%). Depression was associated with cohabiting with spouses with alcohol-related problems. Results reveal that the association between depression and alcohol consumption is distinct between genders.
\end{abstract}

Key words Depression, Alcohol, Gender, Epidemiological survey
Resumo Como parte do projeto GENACIS, este artigo visou estimar a prevalência de depressão em amostra urbana de São Paulo, Brasil, assim como a associação entre depressão e padrão de uso de álcool segundo gênero. Para tanto, foi realizado inquérito epidemiológico com amostra probabilística e por conglomerados, com um total de 2083 adultos. Utilizou-se o CIDI SF para identificação de depressão. A análise estatística utilizou o teste de Rao Scott e regressão logística multivariada. A taxa de resposta foi de 74,9\%. Predominaram mulheres $(58,8 \%)$, menores de 40 anos de idade (52\%). A prevalência de depressão foi de 28,3\% para as mulheres e $12,7 \%$ para os homens. Entre os homens, 61,1\% são de bebedores no último ano e a depressão esteve associada ao padrão de consumo de álcool, à maior frequência de binge drinking e à presença de problemas decorrentes do álcool. Entre as mulheres, 69,5\% são abstinentes e a depressão se associou à convivência com cônjuge com problemas devidos ao álcool. Os resultados ressaltam que a associação entre depressão e consumo de álcool é distinta entre os gêneros.

Palavras-chave Depressão, Álcool, Gênero, Levantamento epidemiológico 


\section{Introduction}

Alcohol is the main substance of abuse consumed worldwide and responsible for high morbidity and mortality rates ${ }^{1}$. Data presented by the World Health Organization show that around two billion people over 15 years of age have alcoholic drinks on an yearly basis. The negative consequences derived from such consumption (for example: acute intoxication, alcohol-induced cirrhosis, car crashes) stand for 1.2 deaths for each 1,000 alcohol drinkers (approximately $6 \%$ of all deaths among men and $1 \%$ among women $)^{2}$. Alcohol-related issues cause even greater concern in Latin America, where $16 \%$ of useful life years are lost owing to inappropriate alcohol consumption - an index four times higher than the world average $e^{2,3}$.

In Brazil, epidemiological studies point to the relevance of alcohol consumption as a serious public health issue. Data obtained from the I National Survey on Psychotropic Drug Use (2001) revealed that $68.7 \%$ of the total population had used alcohol in their lives. Among those, $11.2 \%$ (17.1\% among men and 5.7\% among women) met dependence criteria ${ }^{4}$. More recently, the I National Survey on Alcohol Consumption in the Brazilian population revealed that $52 \%$ of brazilians over 18 years of age consume alcohol at least once a year $(65 \%$ of men and $41 \%$ of women). Among these drinkers, $60 \%$ of men and $30 \%$ of women presented a high risk consumption pattern featured by the usual intake of at least five drinks per occasion ${ }^{5}$. Such results give serious cause for concern once the troublesome consumption of alcohol is followed by a great deal of negative consequences such as, for instance, physical and mental health problems, high suicide rates and different types of violence ${ }^{5-8}$.

The association of problematic alcohol consumption with mental disorders is quite usual and among this disorders, depression is undoubtedly the most prevalent ${ }^{1,8,9}$. The Epidemiological Catchment Area (ECA) showed that individuals facing alcohol dependence and/or abuse (ADA) presented an Odds Ratio (OR) of 1.7 to go into depression. Among men with ADA, 5\% fell into depression along their lives, in comparison to $3 \%$ of the general male population. Among women with ADA, 19\% fell into depression along their lives, in comparison to $7 \%$ of the general female population ${ }^{10}$. The National Epidemiological Survey on Alcohol and Related Conditions (NESARC, 2004) showed a positive association of disorders related to alcohol consumption with depression within the last 12 months featuring a OR of $2.2^{11}$.
Establishing the reasons for such association is not an easy task, mainly through epidemiological surveys. Nevertheless, a few theories have tried to cope with such reasons as depression and problematic use of alcohol present similar characteristics that may lead to their co-occurrence. Both conditions are rather prevalent and might occur either randomly or due to common risk factors such as psychological suffering and personal as well as family or social damage ${ }^{12,13}$. Alcohol is often used to alleviate the afflictive symptoms of humor disorders; on the other hand, abstinence in chronic alcohol users goes along with anguish and psychic discomfort. On the biological side, the chronic use of alcohol leads to neurochemical changes that show up as depression, overestimating its prevalence in those individuals, mainly women, for whom the organic consequences derived from alcohol abuse are more serious when compared to the ones experienced by men ${ }^{14}$. On the psychosocial side, problematic female drinkers are not as much tolerated by society as men, and therefore the negative consequences of alcohol abuse are worse for women ${ }^{1,15-17}$. For females, the problematic use of alcohol is usually secondary to depression ${ }^{14,16,17}$.

As the association of alcohol use with depression is a complex issue, it is extremely important to understand both conditions, their means of prevalence and forms of mutual association as well as with socioeconomic variables. National research approaching this association is scarce so this paper is a contribution to such a relevant theme.

\section{The GENACIS Project}

The Gender, Alcohol and Culture, an International Study (GENACIS) Project is a multicentric study carried out in over 35 countries. Its general objective is to investigate how both individual and social features are associated with the consumption of alcohol for men and women inserted in their different cultures. With the support of the Pan-American Health Organization (PAHO), American countries such as Canada, the USA, Mexico, Costa Rica, Belize, Peru, Chile, Argentina, Uruguay and Brazil have already taken part of the project. In Brazil, the sample included 2,083 adults living in the metropolitan region of São Paulo from November 2005 to June 2007.

The present paper is a part of the GENACIS Project. The data presented herein refer to the occurrence and the risk factors of depression and are aimed at: 1) assessing the prevalence of depression in an urban sample from the metro- 


\section{Methods}

\section{Sample}

A significant sample of 2,083 adult individuals living in the metropolitan region of São Paulo was selected through a probabilistic sample process and through clusters (census sector and domicile) according to the census performed by the Brazilian Institute of Geography and Statistics (IBGE) in $2000^{18}$. Special populations such as institutions, commercial establishments and student-shared housings were not considered. An over-representation of people over 60 years of age was noticed. Further information about the sampling process as well as about other methodological issues is provided by Taylor et al. ${ }^{19}$.

\section{Data Collection}

Data were obtained through a household interview survey and involved only individuals who were intellectually capable for the task and not presenting any evidence of intoxication by means of alcoholic liquor or any other drug. More than one interview was allowed as to make questionnaire completion feasible. The interviewers were duly trained for data collection using the tool. This GENACIS Project approach was approved by the Ethics Research Committee of the Medical School of Botucatu, University of the State of São Paulo (UNESP) on October 2, 2006. Participants were free volunteers who signed an Informed Consent beforehand. Their answers followed a scheme of non-disclosure rules, and they were granted the right to quit the project at any time without being imposed any penalties related thereto. The collection was carried out from November 2005 to June 2007.

\section{Instrument}

The GENACIS questionnaire was used ${ }^{20}$. It comprises 119 closed-ended questions divided into 15 blocks approaching the following themes: socioeconomic features, labor experiences, social and family networks, alcohol use variables (quan-

tity and frequency of use), drinking contexts, consequences of the drinking habit, physical and mental health evaluation, private relationships, marital violence, and victimization.

\section{Dependent Variables: Depression}

The occurrence of depression was investigated by taking the Composite International Diagnostic Interview Short-Form (CIDI SF) as a starting point. It comprises a series of scales concerned with the DSM IV diagnosis criteria and derived from the full $\mathrm{CIDI}^{21}$.

This instrument optimizes the screening of the main psychiatric syndromes, which makes its applicability easier for epidemiological studies (average application time: 10 minutes). Its sensitivity amounts to $98 \%$, with a specificity rate of $72.7 \%$ and accuracy of $93 \%$ when compared to CIDI in its full version ${ }^{22}$.

\section{Independent Variables}

\section{Socioeconomic Features}

The following was selected: gender, age bracket, marital status, educational background, income per capita, religion and its importance for the individual's life.

\section{Alcohol Consumption Features}

Alcohol consumption was standardized as one drink containing 13 grams of ethanol for the average size of a Brazilian drink presents 12 to 15 grams. The alcohol consumption pattern was divided into five categories from the average quantity of drinks that someone has on a typical day within the last 12 months. Individuals were deemed as abstemious for life when they had never made use of alcohol or when their alcohol intake was insignificant; currently abstemious were the ones who had not have any alcohol for the last 12 months; mild drinkers were the ones who had 1 to 2 drinks; moderate drinkers were the ones who had 3 to 4 drinks; and heavy drinkers were the ones who had more than 5 drinks. Heavy drinkers, also referred to as belonging to the binge drinking category, were associated with a high chance of hazards, being considerably prevalent among individuals presenting mental disorders $^{7,10}$. This study also considered this variable as a possible factor associated with depression. It also included the "monthly frequency of binge drinking episodes" question. In addition, the presence of any problem derived from alcohol consumption was investigated within the last 12 months by taking the following question as a 
starting point: "Is there any problem in your life caused by alcohol consumption?" The following questions were analyzed in order to define the context of consumption: "do you usually drink alone?”, "do you feel yourself sexually uninhibited when drinking?", and "are you more outspoken when drinking?" The criteria for the categorization of problems derived from alcohol intake among family members and for the consumption pattern of the spouses were similar to the ones employed with the individuals. This pattern was compacted into three categories: abstemious/mild; moderate or heavy.

\section{Statistical Analyses}

Associations between depression, alcohol consumption pattern and each selected socioeconomic variables were investigated by the RaoScott test by adjusting data according to the weighting factors as the case implies complex sampling $^{23}$. For the conjoint analysis about the action of independent variables on the presence of depression, the multivariate analysis through logistic regression was used in the Stata 10.0 program taking Odds Ratio as an element of comparison. Confidence intervals were estimated for the same significance level of $5 \%{ }^{24}$. For a start, all the variables selected in the process for ulterior elimination were included in case the respective significance levels were above 5\%. The analyses were carried out separately for both men and women. For the best interpretation of the results stemming from the logistic regression, the variables referring to alcohol consumption were divided into two groups: 0 as reference and 1 as contrast. The exception was the standard alcohol consumption variable, which remained with five categories for the individuals and three categories for the spouses. Information about "I don't know", "did not answer" and "missing" was not taken into account.

\section{Results}

The response rate was $74.9 \%$. Prevalence corresponded to women $(58.3 \%)$, individuals under 40 years of age, and to formally or informally married among men $(64.3 \%)$ and women (54.5\%). Widows were $8.4 \%$ and widowers were $5.0 \%(\mathrm{p}<0.001)$. Lower degrees of education were associated with the older age brackets for both genders. Two thirds of men earned regular wages in comparison to $45.5 \%$ of women. Among students, however, $32.0 \%$ were women and only
$7.5 \%$ were men $(\mathrm{p}<0.001)$. Even after the counterbalances of the analyses performed between genders, women presented a lower monthly income $(\mathrm{p}<0.001)$ and more women answered that religion is important for their lives when compared to men $(\mathrm{p}<0.001)$.

In relation to alcohol use, both men and women presented distinctive features, excepted only for the mild consumption that was similar between the genders (Table 1). The frequency of abstinence was higher for women $(p<0.001)$ whereas the prevalence of heavy consumption was higher for men $(p<0.001)$. Mild consumption was similar between men and women ( $\mathrm{p}<$ $0.001)$. Age bracket was also associated with alcohol consumption for both genders with increasing abstinence prevalence according to the age and the heaviest consumption rates being more frequent among youngsters.

Binge drinking occurring more than once a month was greater among men if compared to women $(p<0.001)$ as well as the occurrence of problems derived from alcohol consumption ( $\mathrm{p}$ $<0.001)$. Men drink alone three times more often than women $(p<0.001)$. They also feel themselves more outspoken when drinking $(p<0.03)$. No difference was found between genders when it refers to feeling sexually uninhibited (a) when drinking $(\mathrm{p}=0.9)$ and when it refers to the presence of family members presenting problems derived from alcohol consumption $(\mathrm{p}=0.09)$. Living with a spouse who presents either a moderate or heavy alcohol consumption pattern was more frequent to women $(28.6 \%$ versus $7.3 \%$, p $<0.001)$ as well as having family members who present problems derived from alcohol consumption $(21.4 \%$ versus $5.2 \%, \mathrm{p}<0.001)$.

The univariate associations between depression and each one of the explicative variables are displayed in Table 2. The prevalence of depression was $21.8 \%$, among which $28.3 \%$ were women and $12.7 \%$ were men $(\mathrm{p}<0.001)$. Among women, depression was associated with occupation $(\mathrm{p}<0.001)$ with a prevalence of $43.3 \%$ among the ones earning a regular wage and of $31,3 \%$ among the ones unemployed. Still about women, depression was associated with living with a spouse who presents problems derived from alcohol consumption $(\mathrm{p}<0.001)$ with a prevalence about 52.9\%.

Among men, depression was associated with age bracket $(\mathrm{p}<0.05)$ presenting the highest indices from 40 to 49 years of age $(24.5 \%)$. Among them, depression was associated with the alcohol consumption pattern $(\mathrm{p}<0.05)$ with the highest rates among moderate drinkers $(16.0 \%)$ and 
Table 1. Alcohol consumption features in the sample according to gender in the city and metropolitan region of São Paulo, 2005 to $2007(\mathrm{~N}=2,083)$.

\begin{tabular}{|c|c|c|c|c|c|}
\hline & \multicolumn{2}{|c|}{$\begin{array}{c}\text { Women }^{*} \\
\mathrm{~N}=1216(58.3 \%)\end{array}$} & \multicolumn{2}{|c|}{$\begin{array}{c}\operatorname{Men}^{*} \\
\mathrm{~N}=861(41.7 \%)\end{array}$} & \multirow[t]{2}{*}{ p value v $^{* *}$} \\
\hline & $\mathbf{N}$ & $\%$ & $\mathbf{N}$ & $\%$ & \\
\hline \multicolumn{6}{|l|}{ Alcohol consumption pattern } \\
\hline Abstemious for life & 597 & 49.7 & 138 & 16.0 & \multirow[t]{5}{*}{$<0,001$} \\
\hline Currently abstemious & 240 & 19.8 & 215 & 24.9 & \\
\hline Mild & 258 & 21.5 & 181 & 21.0 & \\
\hline Moderate & 68 & 5.6 & 150 & 17.4 & \\
\hline Heavy & 39 & 3.2 & 178 & 20.6 & \\
\hline \multicolumn{6}{|l|}{ Binge drinking } \\
\hline Up to once a month & 333 & 90.0 & 358 & 70.7 & \multirow[t]{2}{*}{$<0,001$} \\
\hline More than once a month & 37 & 10.0 & 148 & 29.3 & \\
\hline \multicolumn{6}{|c|}{ Problems derived from alcohol consumption? } \\
\hline No & 103 & 78.0 & 269 & 36.9 & \multirow[t]{2}{*}{$<0,001$} \\
\hline Yes & 29 & 22.0 & 459 & 63.1 & \\
\hline \multicolumn{6}{|l|}{ Do you usually drink alone? } \\
\hline No & 329 & 89.4 & 356 & 70.5 & \multirow[t]{2}{*}{$<0,001$} \\
\hline Yes & 39 & 10.6 & 149 & 29.5 & \\
\hline \multicolumn{6}{|c|}{ Sexually uninhibited when drinking? } \\
\hline No & 285 & 78.1 & 217 & 77.7 & \multirow[t]{2}{*}{0.9} \\
\hline Yes & 80 & 21.9 & 12 & 22.3 & \\
\hline \multicolumn{6}{|c|}{ Are you more outspoken when drinking? } \\
\hline No & 199 & 84.7 & 237 & 74.1 & \multirow[t]{2}{*}{0,02} \\
\hline Yes & 36 & 15.3 & 83 & 25.9 & \\
\hline \multicolumn{6}{|c|}{ Spouse: Problems derived from alcohol consumption? } \\
\hline No & 377 & 78.5 & 217 & 94.7 & \multirow[t]{2}{*}{$<0,001$} \\
\hline Yes & 103 & 21.5 & 12 & 5.3 & \\
\hline \multicolumn{6}{|c|}{ Family members: Problem alcohol use? } \\
\hline No & 858 & 71.4 & 642 & 75.7 & \multirow[t]{2}{*}{0,09} \\
\hline Yes & 344 & 28.6 & 206 & 24.3 & \\
\hline \multicolumn{6}{|c|}{ Spouse's alcohol consumption pattern } \\
\hline Abstemious/Mild & 574 & 71.4 & 661 & 92.6 & \multirow[t]{3}{*}{$<0,001$} \\
\hline Moderate & 115 & 14.3 & 34 & 4.7 & \\
\hline Heavy & 115 & 14.3 & 19 & 2.7 & \\
\hline
\end{tabular}

"Percentage adjusted to sampling design; "* Rao-Scott Test $(\mathrm{p}<0.05)$

the lowest among mild drinkers (7.7\%). Presenting more than a monthly binge drinking episode was also associated with depression with a prevalence rate of $16.3 \%(\mathrm{p}<0.05)$ in addition to the presence of personal problems derived from alcohol intake $(16.0 \%$; $<<0.05)$.

Results obtained from the logistic regression showed that age, included in the analysis as a continuous variable, was associated with depression as a protective factor among women and as a risk factor among men. Among women, in the presence of other variables, depression was associated with belonging to a protestant religion (OR 11.7, $\mathrm{p}<0.05$ ) and living with a spouse who presents problems derived from alcohol consumption (OR 88.3, p < 0.01). Among men, in the presence of other variables, depression was associated with income per capita, the presence of personal problems derived from alcohol consumption and having moderate alcohol consumption. Living with a spouse who presents a moderate alcohol consumption pattern was a protective factor for depression among men. The remaining variables did not maintain their associations after logistic regression (Tables 3 and 4).

\section{Discussion}

Before comparing data with information available in the literature, a few limitations of the study will be put into question. First of all, the transver- 
sal design does not allow casual interference as exposures and outcomes are simultaneously observed. Regarding the reliability of self-reporting, it is important to consider the singularities of memory in a study that made use of an extensive and detailed data collection instrument. In addi-

Table 2. Prevalence of depression between different alcohol consumption features according to gender $(\mathrm{N}=2,083)$.

\begin{tabular}{|c|c|c|c|c|}
\hline \multirow[b]{2}{*}{ Alcohol Consumption Features } & \multicolumn{2}{|c|}{ Women $(58.3 \%)$} & \multicolumn{2}{|c|}{ Men $(41.7 \%)$} \\
\hline & $\begin{array}{c}\text { Prevalence of } \\
\text { depression }(\%)^{*}\end{array}$ & $\begin{array}{c}\mathrm{p} \\
\text { value }^{* *}\end{array}$ & $\begin{array}{c}\text { Prevalence of } \\
\text { depression }(\%)^{*}\end{array}$ & $\begin{array}{c}\mathrm{p} \\
\text { value }^{* *}\end{array}$ \\
\hline \multicolumn{5}{|l|}{ Consumption pattern } \\
\hline Abstemious for life & 26.2 & 0.30 & 13.7 & 0.02 \\
\hline Currently abstemious & 31.7 & & 14.0 & \\
\hline Mild & 24.2 & & 7.7 & \\
\hline Moderate & 41.2 & & 16.0 & \\
\hline Heavy & 33.3 & & 12.5 & \\
\hline \multicolumn{5}{|l|}{ Binge drinking frequency } \\
\hline Up to once a month & 28.7 & 0.40 & 10.6 & 0.03 \\
\hline More than once a month & 32.4 & & 16.3 & \\
\hline \multicolumn{5}{|l|}{ Problems derived from alcohol consumption } \\
\hline Absent & 28.1 & 0.90 & 8.5 & 0.05 \\
\hline Present & 41.4 & & 16.0 & \\
\hline \multicolumn{5}{|l|}{ Do you usually drink alone? } \\
\hline No & 29.3 & 0.8 & 10.1 & 0.06 \\
\hline Yes & 28.2 & & 17.0 & \\
\hline \multicolumn{5}{|l|}{ Spouse presents alcohol-derived problems? } \\
\hline No & 24.7 & 0.00 & 16.1 & 0.8 \\
\hline Yes & 52.9 & & 16.7 & \\
\hline \multicolumn{5}{|c|}{$\begin{array}{l}\text { Any family member presenting problematic } \\
\text { use of alcohol? }\end{array}$} \\
\hline No & 26.5 & 0.3 & 10.7 & 0.06 \\
\hline Yes & 32.9 & & 18.5 & \\
\hline \multicolumn{5}{|l|}{ Spouse's alcohol consumption pattern } \\
\hline Abstemious/Mild & 25.8 & 0.07 & 12.7 & 0.3 \\
\hline Moderate & 31.3 & & 5.9 & \\
\hline Heavy & 37.4 & & 10.5 & \\
\hline
\end{tabular}

${ }^{*}$ Percentage adjusted to sampling design; ${ }^{* *}$ Rao-Scott Test $(\mathrm{p}<0.05)$

Table 3. Results obtained from logistic regression for depression among women - city and metropolitan region of São Paulo, 2005 to $2007^{*}(\mathrm{~N}=86)$

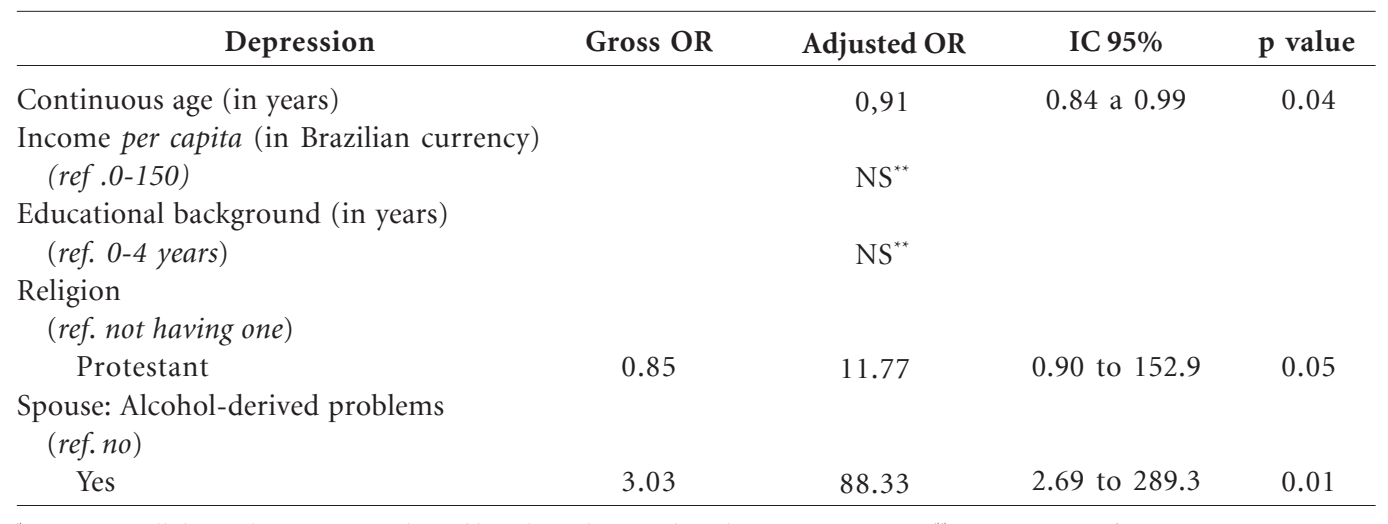

${ }^{*} \mathrm{~N}=2,083$. All the analyses were conducted by taking the sampling design into account; ${ }^{* *} \mathrm{NS}=$ non-significant. 
Table 4. Results obtained from logistic regression for depression among men - city and metropolitan region of São Paulo, 2005 to $2007^{*}(\mathrm{~N}=151)$.

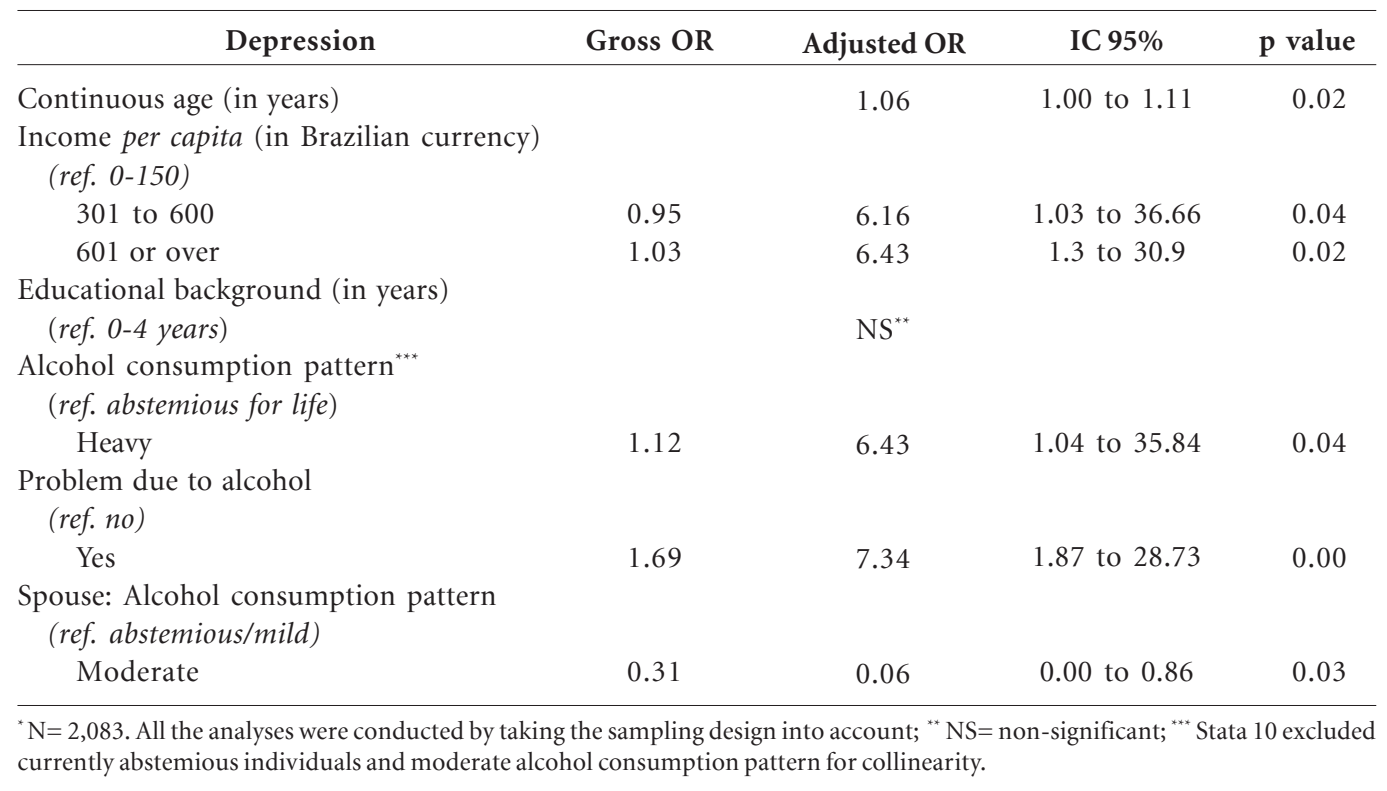

tion, people who agree to participate in surveys are usually more concerned with health and prone to avoid exposing themselves in risk situations. On the other hand, the ones who refuse to participate might be afraid of exposing their problems ${ }^{25}$. A point that must be considered is that the relatively ample confidence intervals occurred because of the scarce individuals in some subgroups. At last, the particular features presented by each gender were not taken into account for the formation of the alcohol consumption categories due to limitations encountered in the GENACIS questionnaire. The results suggested that gender is a relevant factor for the association between alcohol consumption and depression.

As far as alcohol consumption is concerned, according to literature findings, men usually drink more and in a more harmful way than women $^{1,5,25,26}$. Such consumption was evaluated by measuring alcohol intake through the number of doses in each occasion. This is a faithful parameter as much as it refers to the association with negative consequences derived from alcohol intake $e^{27,28}$, although measuring alcohol consumption patterns is considered as a controversial issue and that the strategy in use can underestimate the types of prevalence caused by abusive use ${ }^{29,30}$. In Brazil, the I National Survey on Consumption Patterns of Alcohol and Other Drugs found that $65 \%$ of men are drinkers in comparison to $41 \%$ of women, and that heavy consumption was reported by $38 \%$ of men and
$17 \%$ of women, whereas mild consumption was reported by $38 \%$ of men and $63 \%$ of women ${ }^{5}$.

In relation to depression, the prevalence among women was two times greater than among men so the proportion between genders is maintained as informed by the international literature $^{31,32}$. In Brazil, an epidemiological survey carried out in the city of São Paulo reported depression in $13.5 \%$ of men according to CID criteria, whereas $19.2 \%$ of women presented such condition $^{33}$. It should be noticed that the present study made use of a depression screening instrument so results may have been overestimated ${ }^{21}$.

Depression was also associated with age as observed in many studies but with a different influence on each gender ${ }^{27,32,33}$. While prevalence decreases among men as time passes by, it increases among women from puberty to menopause, when it begins to descend ${ }^{32,33,34}$. The Canadian National Population Health Survey (CNPHS) found that the prevalence of depression among men varied from "insignificant" for individuals over 65 years of age to $5.2 \%$ for youngsters between 12 and 24 years of age. Among women, rates amounted to $3.1 \%$ for individuals over 65 and $9.6 \%$ for youngsters between 12 and 24 years old ${ }^{32}$.

Income per capita was also associated with depression among men, though not among women. Belonging to a protestant religion was associated with depression among women, though not among men. These findings are not 
shared by the literature in which socioeconomic features such as marital situation, income per capita, educational background or religion are not associated with depression ${ }^{31-33}$.

The association between alcohol consumption and depression is quite explored by the literature, but it is not largely known how depression prevalences are distributed along the continuum of alcoholic liquor consumption. Recent researches have shown that abstemious individuals presented more mental suffering if compared to mild and moderate drinkers, thus bringing into question the fact that abstinence is not necessarily connected to improved mental health ${ }^{35,36}$. Rodgers et al. found that abstemious share many characteristics with heavy drinkers such as low socioeconomic status, stressful life events during the last years, and poor social life and leisure ${ }^{35}$. In Brazil, at least among men, alcohol consumption is socially more acceptable than abstinence, which brings a certain social comfort to drinkers when compared to abstemious individuals ${ }^{16}$.

In this study, the association between depression and alcohol consumption pattern was nonlinear. The association for men and women followed the shape of a letter "M" (Figure 1), representing the fact that currently abstemious individuals are more depressed than abstemious for life. It also shows that moderate drinkers present more depression than mild and heavy drinkers, although these results are not statistically significant for the female population $(\mathrm{p}>0.05)$. It is noticeable that currently abstemious individuals can be former problematic drinkers and that, even in sustained abstinence, they can still live with damages caused by harmful alcohol consumption, such as health problems, marital or financial problems, thus justifying the greater prevalence of depression in this population. The less significant prevalence of depression among heavy drinkers suggests that the ones who survived high mortality derived from heavy alcohol consumption would be more resistant to depression or would not acknowledge mental suffering as depression. For men, after the control for all independent variables, only the moderate alcohol consumption pattern supported the positive association with depression.

In addition to the individual characteristics of alcohol consumption, it should be considered that many aspects of the environment where one lives have some impact on mental health, including the relation with people who present problematic alcohol use. Homish \& Leonard reported that women are more susceptible to depression when their husbands are alcoholics ${ }^{37}$. Men, on their turn, are more susceptible to depression when they present individual problems derived from alcohol use. Living with an alcoholic wife does not increase their depression prevalences ${ }^{37}$. In a study performed in clinical sampling, Oliveira found that wives of alcohol-dependent husbands presented high anxiety rates, more stressful life events within the last months, and presented a poorer social life ${ }^{38}$.

The most relevant finding of the present study was the strong association - found in women between depression and living with a spouse presenting problems derived from alcohol consumption. These results show that women present emotional distress due to living in a domestic environment influenced by problems caused by alcohol consumption, even when such problems do not derive from self consumption. Among men, depression was associated with the presence of personal problems derived from alcohol consumption. Among men, on the other hand, living with a spouse presenting moderate consumption showed

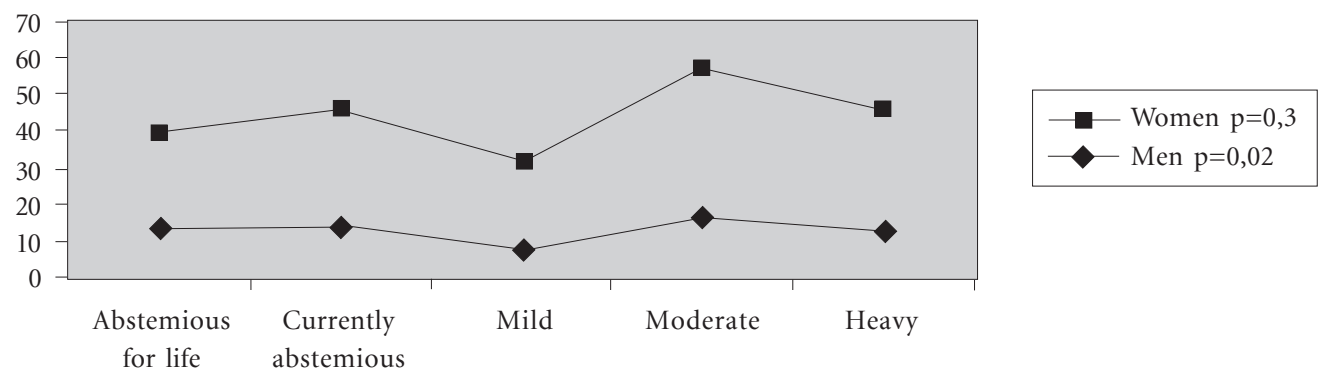

Figure 1. Prevalence of depression according to the alcohol consumption pattern between men and women. 
up to be a protective factor against depression. This is probably due to the presence of a family environment that is more permissible to alcohol consumption. Homish \& Leonard reported that alcohol consumption in a few family scenarios play a modulating role of daily life stress and that such relation is different among men and women ${ }^{37}$.

Despite the consequences of alcohol consumption among women, in Brazil this topic isn't covered by the National Women's Health Politics ${ }^{39}$, and isn't even set a priority of the pacts recently signed $^{40}$. There is no doubt that women constitute a group with many distinct characteristics from men concerns to alcohol, so that it becomes necessary to implement health promotion and prevention to consider, in this case, the interfaces between the genders and consumption of alcohol.

\section{Conclusion}

This study confirmed depression as a important public health problem, even when estimated from a screening instrument. It was associated with heavy drinking habits among men and with living with a spouse who presents problems derived from alcohol consumption among women. Therefore, it points to a special feature of alcohol: its capacity to exceed its consequences beyond the alcohol drinker and those consequences also depend upon gender.

The knowledge obtained from those particular forms of association between men and women is essential for the definition of public health policies for the particular groups, potentializing preventive strategies and increasing therapeutic success for the Brazilian population.

\section{Collaborations}

JA Prado, F Kerr-Corrêa, MCP Lima, GGA Silva and JLF Santos participated equally in all stages of preparation of the article.

\section{References}

1. Kerrr-Corrêa F, Tucci AM, Hegedus, AM, Trinca LA, Oliveira JB, Floripes TM. Drinking patterns between men and women in two distinct Brazilian communities. Rev Bras Psiquiatr. 2008; 30(3):235-242.

2. World Health Organization (WHO). Statistical Information System. Geneva: WHO; 2003. [serial on the Internet]. [cited 2009 Feb 19]. Available from: http://www.who.int/whosis.

3. Wilsnack RW, Wilsnack SC. International gender and alcohol research; recent findings and future directions. Alcohol Res Health 2002; 26(4):245-250.

4. Galduróz JCF, Noto AR, Nappo SA, Carlini ELA. First household survey on drug abuse in São Paulo, Brazil, 1999: principal findings. São Paulo Med. J. 2003; 121(6):231-237.

5. Pinsky I, Zaleski M, Laranjeira R, Caetano R. Primeiro levantamento nacional sobre os padrões de consumo de álcool na população brasileira. Rev. Bras. Psiquiatr. 2010; 32(3):214-215.

6. Galduroz JC, Caetano R. Epidemiologia do uso de álcool no Brasil. Rev. Bras. Psiquiatr. 2004; 26(Supl. 1):3-6.

7. Pechansky F, De Boni R, Diemen LV, Bumaguin D, Pinsky I, Zaleski M. Highly reported prevalence of drinking and driving in Brazil: data from the first representative household study. Rev. Bras. Psiquiatr. 2009; 31(2):125-130.

8. Kessler RC. The Prevalence of Psychiatric Comorbidity. In: Wetzler S, Sanderson WC. Treatment Strategies for Patients with Psychiatric Comorbidity. New Jersey: John Wiley \& Sons, Inc; 1997.

9. Regier DA, Farmer ME, Rae DS, Locke BZ, Keith SJ, Goodwin FK. Comorbidity of mental disorders with alcohol and other drug abuse: Results from the Epidemiologic Catchment Area (ECA) Study. JAMA 1990; 264(19):2511-2518. 
10. U.S. Department of Health and Human Services. Alcohol and Health. Eighth Special Report to the U.S. Congress. Chapter 2 - Psychiatric Comorbidity with Alcohol Use Disorders. Washington: U.S. Congress; 1993.

11. Grant BF, Hasin DS, Stinson FS, Dawson DA, Patricia Chou S, June Ruan W, Huang B. Co-occurrence of 12-month mood and anxiety disorders and personality disorders in the US: results from the national epidemiologic survey on alcohol and related conditions. J Psychiatr Res. 2005; 39(1):1-9.

12. Wang PS, Lane M, Kessler RC, Olfson M, Pincus HA, Wells KB. Twelve-month use of mental health services in the U.S.: Results from the National Comorbidity Survey Replication (NCS-R). Arch Gen Psychiatry 2005; 62(6):629-640.

13. Farrel M, Howes S, Taylor C. Substance misuse and psychiatric comorbidity: an overview of the OOPCS National Psychiatric Morbidity Survey. Addict Behav 1998; 23(6):909-918.

14. Lipton RI. The effect of moderate alcohol use on the relation between stress and depression. Am J Public Health 1994; 84(12):1913-1917.

15. Wilsnack RW, Vogeltanz ND, Wilsnack SC, Harris TR, Ahlström S, Bondy S, Csémy L, Ferrence R, Ferris J, Fleming J, Graham K, Greenfield T, Guyon L, Haavio-Mannila E, Kellner F, Knibbe R, Kubicka L, Loukomskaia M, Mustonen H, Nadeau L, Narusk A, Neve R, Rahav G, Spak F, Teichman M, Trocki K, Webster I, Weiss S. Gender differences in alcohol consumption and adverse drinking consequences: cross-cultural patterns. Addiction 2000; 95(2):251-265.

16. Simão MO, Kerr-Corrêa F, Dalben I, Smaira SI. Alcoholic women and men: a comparative study of social and familial aspects and outcome. Rev Bras Psiquiatr 2002; 24(3):121-129.

17. Massak A, Graham K. The relationship between depression, alcohol use disorder and coping motives for drinking among Canadian men and women. Research on the Comorbidity of Depression and Alcohol Use Disorders. New York: Nova; 1997.

18. Instituto Brasileiro de Geografia e Estatística (IBGE). Base de informações por setor censitário. Censo demográfico IBGE, 2000. Brasília, DF: IBGE. [serial on the Internet]. [cited 2012 Aug 9]. Available from: http://www.ibge.gov.br/home/estatistica/ populacao/censo2000/

19. Taylor B, Rehm J, Aburto JTC, Bejarano J, Cayetano C, Kerr-Corrêa F. Alcohol, gender, culture and harms in the Americas: PAHO Multicentric Study final report. Washington: PAHO; 2007.

20. Projeto Viver Bem. Instrumentos de pesquisa: Questionário GENACIS. [serial on the Internet]. [cited 2012 Aug 9]. Available from: http://www.viverbem. fmb.unesp.br

21. Patten S. Performance of the Composite International Diagnostic Interview Short Form for Major Depression in Community and Clinical Samples. Chronic Dis Can 1997; 18(3):109-112.

22. World Health Organization (WHO). Health Systems Performance Assessment. [serial on the Internet]. [cited 2012 Aug 9]. Available from: http://www3. who.int/cidi/

23. Lee ES, Forthofer RN. Analyzing Complex Survey Data. 2a . Ed. Beverly Hills: Sage; 2006.
24. Hamilton LC. Statistics with STATA. Belmont: Thomsom - Brooks/Cole; 2004.

25. Bobo JK, Husten C. Sociocultural influences on smoking and drinking. Alcohol Res Health 2000; 24(4):225-232.

26. Lima MCP, Kerr-Corrêa F, Tucci AM, Simão MO, Barboza JO. Gender differences in heavy alcohol use: A general population survey. Contemporary Drug Problems 2007; 34(3).

27. Almeida Filho N, Mari JJ,Coutinho E, França JF, Fernandes JG, Andreoli SB, Busnello ED. Estudo multicêntrico de morbidade psiquiátrica em áreas urbanas brasileiras (Brasília, São Paulo e Porto Alegre). Revista ABP-APAL 1992; 14(3):93-104.

28. Lima MCP, Kerr-Correa F, Sansigolo LRF. Uso de substâncias psicoativas e comportamentos de risco. Rev Saude Publica 2009; 43(1):196-198.

29. Anthony JC. The epidemiology of drug addiction. In: Miller NS, editor. Comprehensive handbook of drug and alcohol addiction. New York: Marcel Dekker; 1991. p. 55-86.

30. Graham K, Wilsnack R, Dawson D, Vogeltanz N. Should alcohol measure be adjusted for gender differences? Addiction 1980; 93(8):1717-1727.

31. Angst J. Epidemiology of depression. In: Honig A, Van Praag HM, editors. Depression: neurobiologi$\mathrm{cal}$, psychological and therapeutic advances. Chichester: JohnWiley \& Sons; 1997. p. 17-29.

32. Patten SB. Incidence of major depression in Canada. CMAJ 2000; 163(6):714-715.

33. Andrade LHSG, Gentil Filho CA, Lolio CA, Laurenti R. Epidemiologia dos transtornos afetivos em uma área definida de captação da cidade de São Paulo, Brasil. São Paulo: Relatório do Encontro dos Centros Colaboradores da OMS para ensino e pesquisa em Saúde Mental; 1997.

34. Solomon A. O Demônio do Meio Dia, uma anatomia da depressão. Rio de Janeiro: Objetiva; 2002.

35. Rodgers B, Parslow R, Degenhardt L. Affective disorders, anxiety disorders and psychological distress in non-drinkers. J Affect Disord 2007; 99(1-3):165172.

36. Wilk D. Women and alcoholism: how a male-asnorm bias affects research, assessment, and treatment. Health Soc Work 1994; 19(1):29-35.

37. 37. Homish GG, Leonard KE. Alcohol use, alcohol problems and depressive symptomtology among newly married couples. Drug Alcohol Depend 2006; 83(3):185-192.

38. Oliveira LAC. Aspectos do alcoolismo feminino. Vivência 1998; 54:36-37.

39. Brasil. Ministério da Saúde (MS). Secretaria de Atenção a Saúde. Política Nacional de Atenção Integral à Saúde da Mulher: Princípios e Diretrizes. Brasília: MS; 2004.

40. Brasil. Ministério da Saúde (MS). Pactos de Gestão do SUS. Pacto pela Saúde e pela vida. Brasília: MS; 2006.

Artigo apresentado em 29/05/2011

Aprovado em 23/09/2011

Versão final apresentada em 08/10/2011 